\title{
TREATMENT OF ACID MINE DRAINAGE USING A SANDSTONE COLUMN
}

\author{
H. L. Yadav and A. Jamal \\ Department of Mining Engineering, Indian Institute of Technology, (BHU) Varanasi, India. \\ *E-mail :hiralalyd@gmail.com
}

\begin{abstract}
Acid mine drainage (AMD) or Acid rock drainage (ARD) from mining industry poses worldwide severe environmental problems including India also. In this study, heavy metal removal was tested in AMD samples collected from the Gorbi abandoned coal mine (India), having iron concentrations of $75 \mathrm{mg} / \mathrm{L}$. Sandstone was collected from mine sites and converted into powders form and used as low-cost adsorbent in a column to treat acid mine drainage (AMD) obtained from the inactive Gorbi opencast coal mines (Singrauli coalfields, NCL). The pH value of the pit water sample improved from 2.48 to 3.90 , along with the removal of, $100 \%$ total iron, Lead ( $\mathrm{Pb})$, Cadmium (Cd), $71 \%$ of the electrical conductivity, $73 \%$ total dissolved solids and $50 \%$ of the salinity.
\end{abstract}

Keywords: Heavy metals, Sandstone Column treatment, and acid mine drainage.

(C) RASĀYAN. All rights reserved

\section{INTRODUCTION}

Many active and abandoned mines all over the world are incessantly releasing acid mine drainage into surface and ground water resources. ${ }^{1-3}$ Acid mine drainage is also known as acid rock drainage had the severe effect on the mining based nation all over the world. Its generation will start with initial stages of mining operations and sometimes continues for a very long time even after mine closures ${ }^{4}$, until famous anyone member (i.e. water, air, and pyrite) absent from the generation site. Acid mine drainage has been generated in open pits workings spoil heaps, mine tunnels, waste rock piles ${ }^{5}$, tailings ponds or mineral stockpiles. ${ }^{6}$ The generation of AMD and its impacts depended on many environmental factors and presently it is increased by the defective management of different mining ${ }^{7}$ and industrial activities. The primary sources of AMD generation are mainly pyrite and pyrrhotite ${ }^{8}$, presence in coal. Coal deposits contain 1-20\% amounts of pyritic-sulfur and these strata normally establish with the coal, which exposed to water and oxygen ${ }^{9}$. The oxidation process may be also influenced by some bacteria present in the system from small to large scale by accelerating oxidation of sulfides. ${ }^{10}$ The geological and hydrological condition of the sites of the strata is also critical for acid mine drainage generation.

Mining effluents are characterized by low $\mathrm{pH}^{11-14}$ high acidity, turbidity, total dissolved solids and high metal contents ${ }^{15-17}$ with high concentrations of iron. These metals leads to decline in concentration of dissolved oxygen (DO) in the water resources ${ }^{18}$ a combination which occur that in several cases, mining effluents cause severe environmental nuisance such as poisoning of aquatic organisms and acidification1 with the harmful impact on human health, animals life, plants, vegetation, and natural ecosystem ${ }^{19-20}$, soil quality $^{21-22}$ and corrosion of many mining tools and structures ${ }^{23}$ surrounding mining areas. Some technologies are available for treatment of acid mine drainage ${ }^{24-25}$ and industrial wastewater. Amongst them, few traditional worldwide processes are precipitation ${ }^{26-28}$ ion exchange, ${ }^{12,29-30}{ }^{\text {ultrafiltration, }}{ }^{3-}$ ${ }^{32}$,reverse osmosis, ${ }^{5,33-34}$ nanofiltration, ${ }^{35}$ electrodialysis, ${ }^{36-37}$ coagulation, ${ }^{38-41}$ flocculation, ${ }^{42-44}$ flotation, ${ }^{45}$ electrochemical process, ${ }^{46-47}$ and Adsorption. ${ }^{48-51}$ However, out of above technology, some have disadvantage like, production of secondary waste (sludge), toxicity, high operation and maintenance costs, skilled personal requirement, reduced efficiency, required excess land and expenses for treatment and management of acid mine drainage, which bound the use of the majority of developed technologies. ${ }^{52-}$

${ }^{54}$ However the adsorption process relatively appears to be a suitable method for treatment of acid mine 
drainage mainly due to its advantages, likes ease in design and feasibility in operation, economically cheaply, easily available adsorbent materials. ${ }^{54}$

\section{Material and Methods}

\section{EXPERIMENTAL}

A sample of acid mine drainage was collected from ditches of Gorbi abandoned mine NCL India. These abounded mine sites contain the massive quantity of mine water. The $\mathrm{pH}$ of collected AMD was 2.48. The sandstone used in this study was obtained from the mine site and crushed in a ball mill and sieve $150 \mu \mathrm{m}$ sizes, in the departmental laboratory. The XRF analysis shows that the chemical composition of the sandstone as follows, Silica $\left(\mathrm{SiO}_{2}\right) 67.87 \%$, Alumina $\left(\mathrm{Al}_{2} \mathrm{O}_{3}\right) 25.43 \%$, Ferric oxide $\left(\mathrm{Fe}_{2} \mathrm{O}_{3}\right) 2.27 \%$, Calcium oxide $(\mathrm{CaO}) 1.70 \%$, Titanium dioxide $\left(\mathrm{TiO}_{2}\right)$ 0.086\%, Potassium oxide $\left(\mathrm{K}_{2} \mathrm{O}\right) 0.560 \%$, and Nickel (II) oxide (NiO) $0.212 \%$.

\section{Methodology}

The water sample was collected from the largest inactive opencast coal mine pit, (Gorbi, Singrauli, India). The raw water sample was collected in twenty, 20 L clean plastic gallons, which were carefully washed with raw water sample before starting water sampling (acid mine drainage) from mine sites. The values of $\mathrm{pH}$, TDS, EC, and temperature were measured in situ using a Hanna multi-parameter (HI 9828), $\mathrm{pH}$ meter. The continuous flow experiments were conducted in a prefix circular column with an external diameter of $25 \mathrm{~cm}$ and $60 \mathrm{~cm}$ in height. At the bottom and top of the column, fine meshes of plastic were attached, followed by glass wool.

Inside in the column $1 \mathrm{~cm}$, deep layer of small size glass beads was placed both the top and bottom portion to provide regular inlet flow of the water sample into the column. The column was then packed with $6.0 \mathrm{~kg}$ sandstone in layers and operated in downward flow at room temperature. Every day, $4500 \mathrm{~mL}$ water sample was passed through the sandstone column in flow rates of $1500 \mathrm{~mL} / \mathrm{hr}$., so that in a month, 135L of water sample had been passed through it. This experimental study was continued for more than two months, during which time, a total of $400 \mathrm{~L}$ of water sample (acid mine drainage) was passed through the sandstone column. Periodically samples were collected from the column outlet at regular time intervals and analyzed for physical parameters like $\mathrm{pH}$ value, temperature, electrical conductivity (EC), total dissolved solids (TDS), salinity and heavy metals.

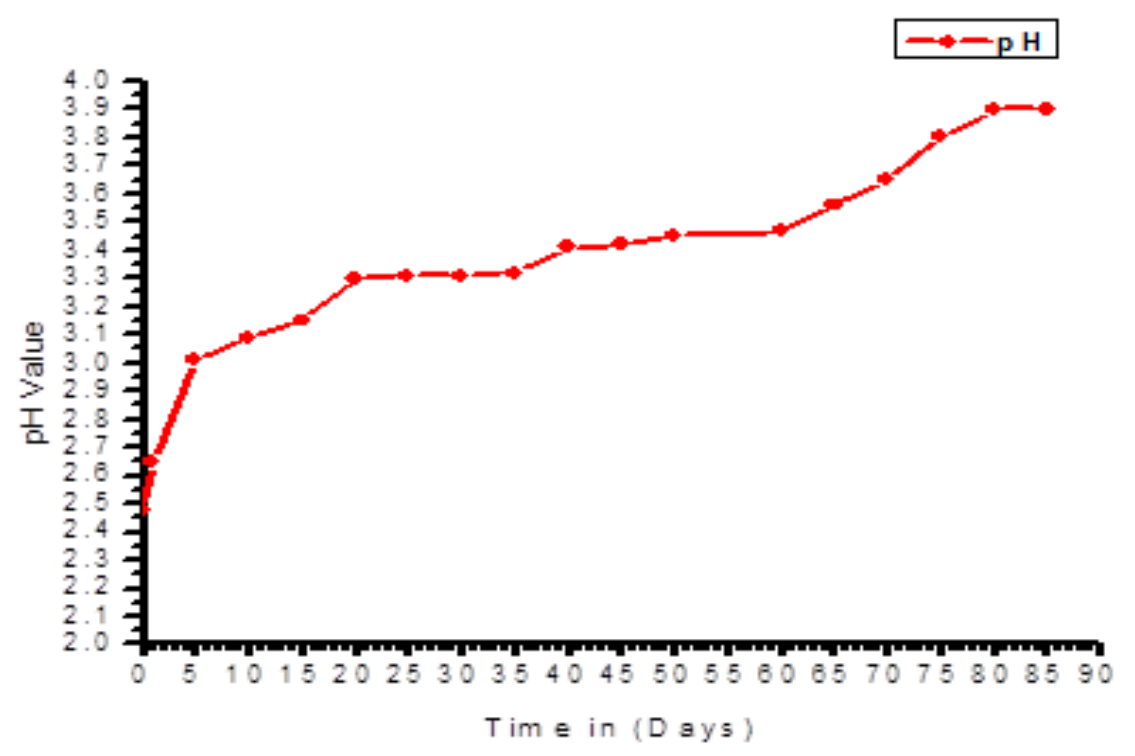

Fig.-1: The $\mathrm{pH}$ value of mine water after treatment through sandstone column 
RASĀYAN J. Chem.

Vol. 10 | No. 3 |891 - 896 | July - September | 2017

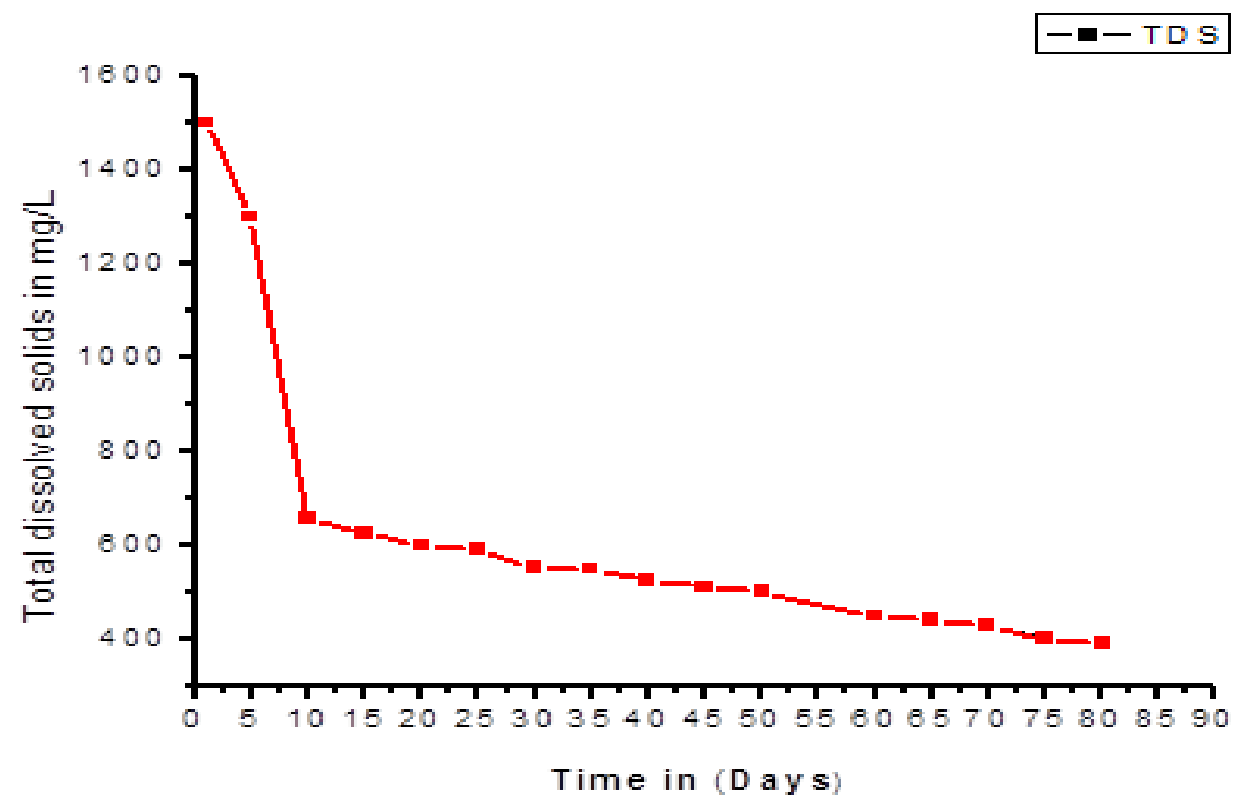

Fig.-2: Removal of TDS from mine water after treatment

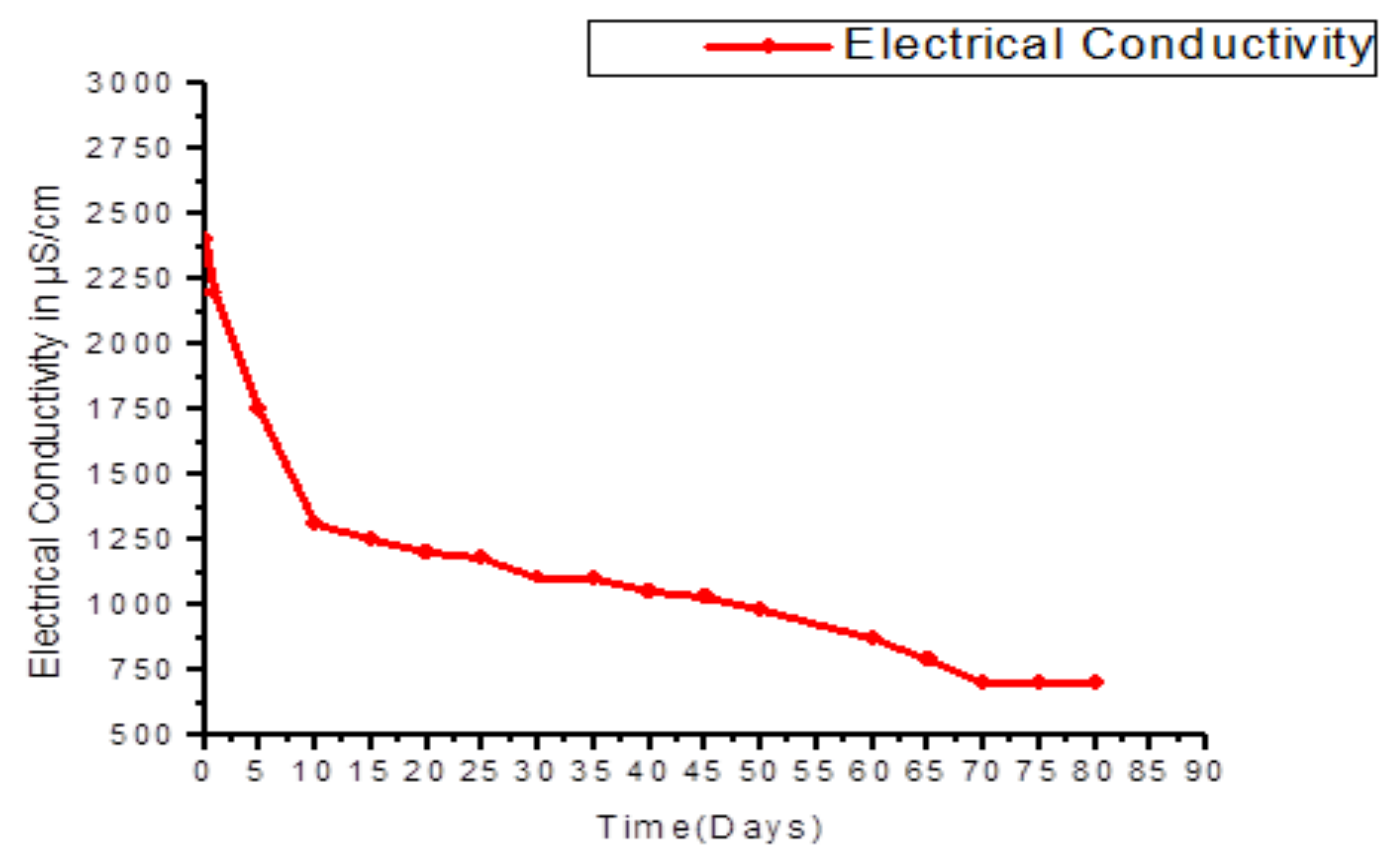

Fig.-3: Removal of electrical conductivity from mine water after treatment

\section{RESULTS AND DISCUSSION}

Water samples were collected from the inactive pits of Gorbi opencast coal mine. The water sample had the initial primary $\mathrm{pH}$ level of 2.48. Water sample passed through the sandstone column since the sandstone is alkaline in nature; the resulting water has high $\mathrm{pH}$ value of the water sample. Removal capacity of heavy metal and decrease in leachate $\mathrm{pH}$ was observed. The water sample of $\mathrm{pH}$ value 3.90 was established after 80 days of sample (AMD) treatment (Fig.-1); after 80 days the increase in $\mathrm{pH}$ attains 
a saturated value of 3.90.The $\mathrm{pH}$ value of water sample was improved due to the composition of the sandstone $\left(\mathrm{SiO}_{2}+\mathrm{Al}_{2} \mathrm{O}_{3}+\mathrm{Fe}_{2} \mathrm{O}_{3}\right)$ and the calcium content. ${ }^{55}$ This increases the $\mathrm{pH}$ value of the solution.

The water sample had initial electrical conductivity (EC) of $2400 \mu \mathrm{S} / \mathrm{cm}$, at the starting of the treatment. The electrical conductivity of the treated water sample was reduced (Fig.-3), at the end of the experimentation, to $700 \mu \mathrm{S} / \mathrm{cm}$. This was almost $71 \%$ of removal of initial Electrical Conductivity of the water sample, which shows the elimination of metals from mine water sample. The initial concentrations of total dissolved solids, $1450 \mathrm{mg} / \mathrm{L}$ was and salinity1.12 PSU in the raw water sample. When the water sample was passed through the sandstone column, the total dissolved solids and salinity are subsequently decreased from the sample water (Fig.-2 and 4) to 390mg/L and 0.6 PSU respectively. The sandstone column was found to be extremely useful in eliminating toxic heavy metals from the AMD, $100 \%$ of iron $(\mathrm{Fe}), 100 \%$ of the lead $(\mathrm{Pb}), 100 \%$ of the cadmium $(\mathrm{Cd})$ were removed after 60,10 and five days of mine water treatment through sandstone column respectively (Fig.-5). The initial metals concentration in the raw water sample (acid mine drainage) was $75 \mathrm{mg} / \mathrm{L}$ iron $(\mathrm{Fe}), 00.066 \mathrm{mg} / \mathrm{L}$ lead $(\mathrm{Pb})$, and 0.006 $\mathrm{mg} / \mathrm{L}$ cadmium $(\mathrm{Cd})$. The main concentration was Iron $(\mathrm{Fe})$ in the water sample. After passing the water sample through the sandstone column, the initial metals concentration of the raw water sample has been decreased to $0.00 \mathrm{mg} / \mathrm{L} \mathrm{Fe}, \mathrm{Pb}$, and $\mathrm{Cd} \mathrm{mg} / \mathrm{L}$. The treatment through sandstone column was very efficient due to the composition of sandstone dominated $(67.87 \%)$ by silicon oxide $\left(\mathrm{SiO}_{2}\right),(25.43 \%)$ Alumina $\left(\mathrm{Al}_{2} \mathrm{O}_{3}\right)$, Ferric oxide $\left(\mathrm{Fe}_{2} \mathrm{O}_{3}\right),(2.27 \%)$ and Calcium oxide $(\mathrm{CaO})(1.70 \%)$, which provides better metal removal efficiency from metal-laden effluents. ${ }^{54-57}$

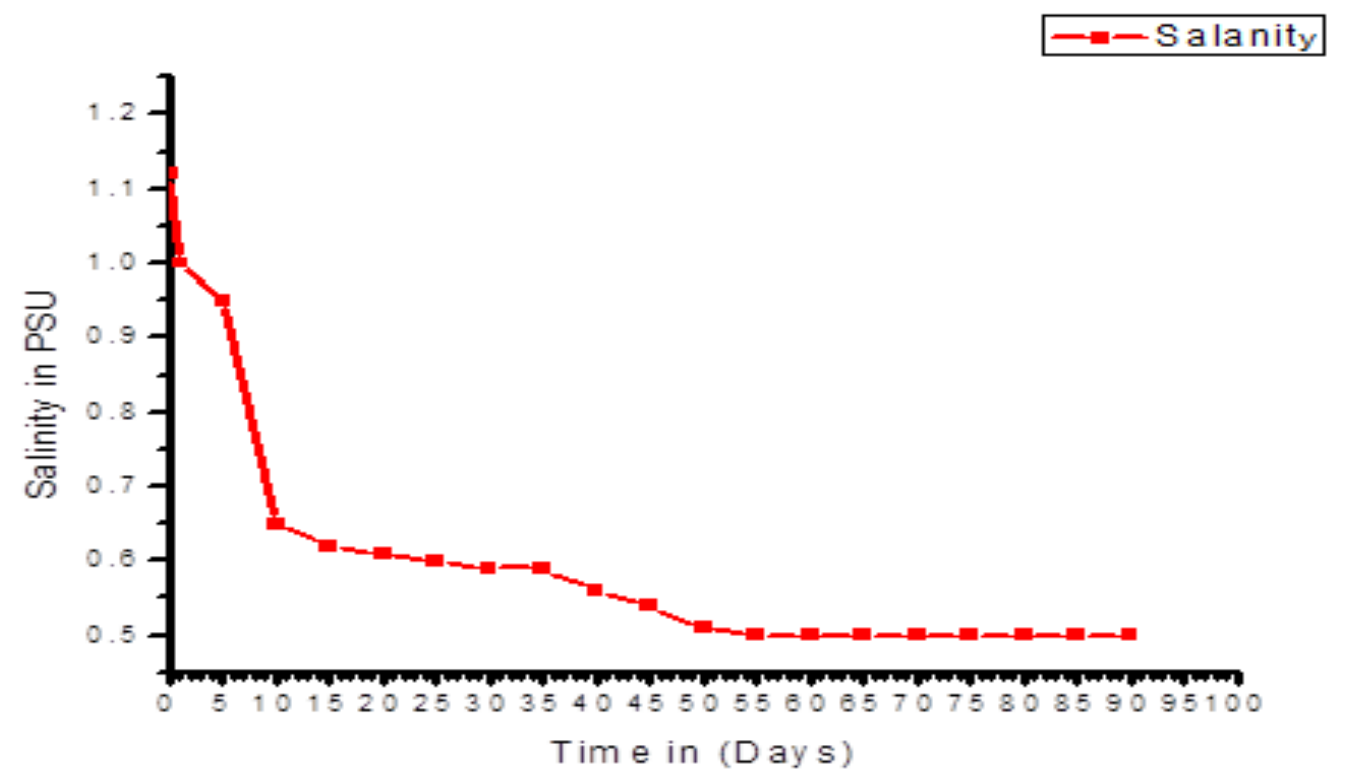

Fig.-4: Removal of salinity after treatment

\section{CONCLUSION}

Sandstone obtained from the local (NCL) mining area was found to be useful for the removal of lead, Cadmium and total iron from the Gorbi opencast mine, effluents. The $\mathrm{pH}$ value of the raw water sample was improved from 2.48 to 3.90 . The uptake of toxic heavy metals from water sample was found $100 \%$ total iron, lead, and cadmium with $71 \%$ reduction in electrical conductivity $73 \%$ TDS and 50\% Salinity. The study results show that sandstone can be used as an economical material for the uptake of lead, cadmium, and total iron from mine water. A suitable field study is essential to estimate the relative economic treatment costs of both treatment process (active and passive) for the successful elimination of toxic heavy metals from the mining and industrial effluents. 


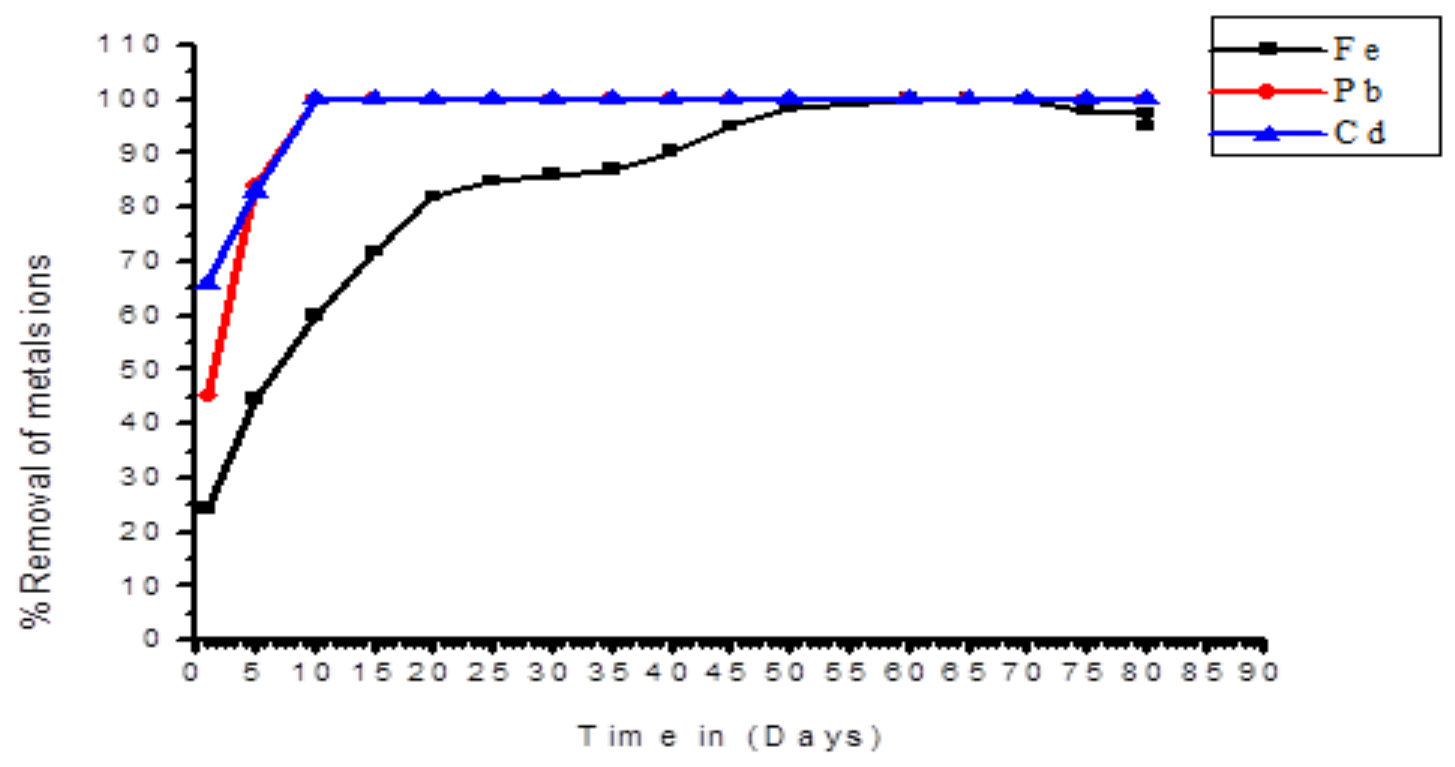

Fig.-5: Removal of heavy metals from mine water after treatment

\section{ACKNOWLEDGEMENT}

The authors are grateful to the Department of Mining Engineering, Indian Institute of Technology, Banaras Hindu University, Varanasi, India, for providing support during the investigation period.

\section{REFERENCES}

1. E. Chockalingam, S. Subramanian, Bioresour Technol., 100(2), 615(2009).

2. E.R. Goetz, R.G. Riefler, Chem Eng J., 240,579(2014).

3. B. Prasad, R.J.G. Mortimer, Water Air Soil Pollut., 218,667(2011).

4. A. S. Sheoran, and V. Sheoran, Miner. Eng., 19 (2), 105(2006).

5. D.B.Johnson, K.B.Hallberg, Sci. Total Environ., 338, 3(2005).

6. F. G. Bell, Environmental Geology (Principles and Practice). Cambridge: Cambridge University Press (1998).

7. P.L.Younger, N.S.Robins, Mine Water Hydrogeology and Geochemistry. Geological Society of London, UK, 1-16 (2002).

8. R.W. Gaikwad, R.W, S.A. Misal, Dhirendra, D.V. Gupta, Arab J. Geosci., 4, 85(2011).

9. I.C. Montero, G.H. Brimhall, C.N. Alpers, G.A. Swayze, Chem Geol., 215,452(2005).

10. Asif Qureshi, Christian Maurice, Bjorn Ohlander, J. of Geochemical Exp., 160,44(2016)

11. H.L.Yadav and A. Jamal, Int. J.of New Tech. in Sci. and Eng., 2(3), 77(2015).

12. H.L.Yadav, and A. Jamal,Int. J. of Advanced Research, 3(10),1009(2015).

13. H.L.Yadav, and A. Jamal, Int. J. of Advanced Research, 4(6),310(2016).

14. B. Prasad, and H. Kumar, Mine Water Environ., 35, 553(2016).

15. A. Alcolea et al., Miner. Eng., 26, 86(2012).

16. H. Davies, P.Weber, P. Lindsay, J .Sci. Total Environ., 409(15), 2971(2011).

17. P.L.Younger, Iron. In: D'Arcy, B., Ellis, J.B., Ferrier, R.C., and Jenkins, A., Dils, R. (Eds.). Terence Dalton Publishers, p. 95-104(2000).

18. H.F. Dallas, and J.A. Day, Water Research Commission Report, TT61/93, (1993).

19. D. M. Kargbo, D.S. Fanning, H. I. Inyang, R.W. Duell, Environ Geol., 22, 218(1993).

20. D. K. Nordstrom, C. N. Alpers, Proc. Natl. Acad. Sci., 96, 3455(1999).

21. D.S. Pelo, E. Musu, R. Cidu, F. Frau, P. Lattanzi, J. Geochem. Explor., 100,142(2009). 
22. P. K. Sahoo, S. Tripathy, S. M. Equeendduin, M.K. Panigrahi, J. Geochem. Explor., 112,235(2012).

23. P.K. Goel, New Age International Publishers, New Delhi, (2006).

24. M. Delkash, Ebrazi, B. Bakhshayesh and H. Kazemian, Micropor.Mesopor. Mater, 214, 224(2015).

25. A. E. Iakovlev, E. Makila, J. Salonen, M. Sitarz, S. Wang, and M. Sillanpaa, Ecol. Eng., 8130(2015).

26. D. Bhattachayya, A. Jumawan, G.Sun, K. Schwitzebel, AICHE Symposium Series, Water; 77, 31 (1980).

27. V. Bologo, J.P. Maree, and F. Carlsson, Water, 38 (1), 23(2012).

28. J.M.Hammarstrom, P.L. Sibrell, H.E. Belkin, Appl. Geochem., 18, 1705(2003).

29. D.C.Buzzi, L.S.Viegas, M.A.S. Rodrigues, A.M.Bernardes, and J.A.S.Tenorio, Miner Eng., 40, 82 (2013).

30. V. K. Gupta, P. J. M. Carrott, M. M. L.Ribeiro Carrott, and Suhas, Environmental Science and Technology, 39(10), 783(2009).

31. J. Landaburu-Aguirre V. Garcia, E. Pongracz, R.L. Keiski, Desalination, 240,262(2009).

32. E.Sampera, M.Rodrigueza, M.A. DelaRubia D. Prats, Sep. Purif. Technol., 65,337(2009).

33. M.A.Barakat, Arabian Journal Chemistry, 4, 361(2011).

34. M. M. Nia, P. Montazeri, H. Modarress, Desalination 217,276(2007).

35. A. Criscuoli, M.S.I. Mozumder, M. T. Uddin, M.A., Islam, E. Drioli, Water Res., 44,97(2010).

36. H. Karami, Chemical Engineering Journal, 219, 209(2013).

37. S. K. Nataraj, K.M. Hosamani, T.M.Aminabhavi, Desalination 217,181(2007).

38. Q. Chang, G. Wang, Chem. Eng. Sci., 62, 4636(2007).

39. S.L.Daniels. AICHE symposium series. Water, 71,265(1975).

40. A. G. ElSamrani, B. S. Lartiges, F. Villieras, Water Res., 42,951(2008).

41. B. Hadj, C. Messaoud, L. Angelique, C. Michel, D.L Stephanie, J. Nanostruct Chem., 4, 98(2014).

42. S. Y. Bratskaya, A. V. Pestov, Y. G. Yatluk, V. A. Avramenko, Colloid. Surf., 339,140(2009).

43. Q.Chang, M. Zhang, J.X. Wang, J. Hazard Mater. 169,621(2009).

44. J.C. Duan, Q.Lu, R.W.Chen, Y.Q.Duan, L.F.Wang, L. Gao, S.Y. Pan, Carbohydr.Polym., 80,436(2010).

45. M. Lundh, L. Jonsson, J. Dahlquist, Water Res., 34, 21(2000).

46. I. Heidmann, W. Calmano, J. Hazard Mater, 152,934(2008).

47. A.G. Vlyssides, C.J., Israilides, Env. Pollut., 97,147(1997).

48. M. X. Guo, G.N. Qiu, W.P. Song, Waste Manage, 30,308(2010).

49. A. Kongsuwan, P. Patnukao, P. Pavasant, J. Ind. Eng. Chem., 15,465(2009).

50. H. G. Park, T.W. Kim, M.Y. Chae, I.K., Yoo, Process Biochem., 42,1371(2007).

51. A. M. Youssef, S. El-Khouly, T.H. El-Nabarawy. Carbon Lett., 9, 8(2008).

52. M. Kalin, A. Fyson, and W.N. Wheeler, Sci. Total Environ., 366 (23) , 395(2006).

53. G. S. Simate, and S. Ndlovu, J. Environ. Chem. Eng., 2(3), 1785(2014).

54. Vhahangwele, Masindi, Mugera Wilson Gitari, Hlanganani Tutu and Marinda De Beer, Water SA, 41(5), 677 (2015).

55. S. D. Faust, O.M. Aly,.Butterworth Publishers, Stoneham, (1987).

56. A.Mishra, and B.D.Tripathi, Toxicological \& Environmental Chemistry, Water SA, 90(6), 1091 (2008).

57. H. Thorwarth, V. Stack-lara, S. Unterberger, \& G. Scheffknecht, Proceedings of Air Quality V. Washington, D.C. (2005).

[RJC-1781/2017] 